\title{
Augmented Reality As a Working Aid for Intellectually Disabled Persons For Work in Horticulture
}

\author{
P. Benda, M. Ulman, M. Šmejkalová \\ Faculty of Economics and Management, Czech University of Life Sciences Prague, Czech Republic
}

\begin{abstract}
Anotace
Hlavním zaměřením tohoto článku je experimentálně ověřit možnosti využití rozšířené reality jako platformy pro zobrazování vzdělávacích materiálů z oblasti zahradnictví v reálném prostředí pro osoby s mentálním postižením. Experimentálního ověření se zúčastnilo osm osob $\mathrm{s}$ různou úrovní mentálního postižení. Účastníkům byl předložen vzdělávací materiál ve formě videa, který byl dosažitelný pomocí platformy Wikitude na základě specifických GPS souřadnic. K nalezení a zobrazení obsahu účastníci využívali zařízení iPad2 a Android tablet. I přes velký potenciál technologie rozšiřené reality nelze na základě provedených šetření v současné době tento způsob vzdělávání pro osoby s mentálním postižením doporučit.
\end{abstract}

\section{Klíčová slova}

Přístupnost, rozšířená realita, mentální postižení, zahradnictví.

\begin{abstract}
The main focus of this article is to verify experimentally the possibility of using Augmented Reality as a platform for display educational materials in the field of horticulture in the real world for people with intellectual disabilities. Experimental verification was attended by eight people with varying levels of mental disability. The educational material was presented to the research participants in the form of a video, which was accessible via Wikitude platform based on the specific GPS coordinates. To find and display the content, participants used iPad2 and Android tablet devices. Despite the great potential of Augmented Reality technology, on the basis of undertaken studies it is still not possible to recommend this type of education for people with intellectual disabilities.
\end{abstract}

\section{Keywords:}

Accessibility, Augmented Reality, intellectual disability, horticulture.

Benda, P., Ulman, M. and Šmejkalová, M. (2015) “Augmented Reality As a Working Aid for Intellectually Disabled Persons for Work in Horticulture", AGRIS on-line Papers in Economics and Informatics, Vol. 7, No. 4, pp. 31 - 37, ISSN 1804-1930.

\section{Introduction}

The main motive for the verification of educational possibilities for people with intellectual disabilities for work in horticulture using Augmented Reality is to support their work activities in real environment and to help address better certain specifics of the mental processes for this group of employees by use of Augmented Reality. Valenta and Müller (2003) divide the specifics of mental processes of mentally disabled persons as follows:

- Thinking - is hampered by excessive concreteness, inaccuracies and mistakes in analysis and synthesis. It is incapable of higher abstraction, thinking is inconsistent concepts are created ponderously, judgments are inaccurate;

- Memory - they acquire new knowledge slowly and only by multiple repetitions, they quickly forgetting and are unable to assert new knowledge into practice on time;

- Attention - shows a low range of the reference field, instability and ease fatigue;

- Will - specific feature is a failure of will, indecision, lack of will, reduction of free activities, the inability to commence their operations. 
By supporting this idea there are also general economic and social reasons. Černá (2009) finds the long-term care more expensive than supported independence and meaningful work. Even low paid employment or part-time job gives a person with mental disability status of the adult who contributes to the society and this employment also efficiently stimulates and maintains its skills and habits.

According to the information published by Tyrychtr et al. (2015) agribusiness could have enough power to support this group of employees: As to the investments to IT, there is a positive rating of the level of information technologies in agribusiness. Most of expenditures on hardware are now directed to mobile technologies.

Thanks to the positive outcome, the support workers were very enthusiastic with the beneficial effects of the touch screen, in particular, the increased attention span and the fact that the students with moderate intellectual disability could act on the computer. Students with moderate intellectual disability often had motor skill deficits that hampered them from manipulating the computer mouse. Because of having the touch screen, their movements did not need to be very precise (Denaes, 2012).

According to the conducted research and in comparison with scientific publications (Huguenin, 2000; Van de Ven and de Haan, 2003; Denaes, 2012; Benda and Šmejkalová, 2015) can be mentioned touch screen as the most suitable technology for controlling web applications by persons with mental disabilities, so these people are able to use and navigate simple mobile learning environment. Goksu and Atici (2013) ads that using mobile learning environment gives learners an opportunity to access the information whenever and wherever they want. Therefore, mobile devices which are sometimes criticized as one of the learning tools and which are developing in extend of size and features have recently been used intensively and they have increased the effectiveness of learning environments. It is also predicted that Augmented Reality will develop and it will increase the efficiency of mobile learning, and also it will be very common in educational institutions.

Gomez et al. (2015) and Hervas et al. (2014) presented a novel wayfinding system adapted for people with cognitive disabilities with use of Augmented Reality. The path planning and presentation have been specifically developed to meet their needs. Therefore, instead of showing complex instructions on maps, it was decided to break down the route into atomic instructions and make use of images at the decision points.

\section{Materials and methods}

Augmented Reality is still a new concept and it is not commonly used by general public despite the fact that it has been described in the nineties already (Azuma, 1997; Bimber and Raskal, 2005; Schmalstieg and Wagner, 2007). This fact can be confirmed also in 2015. Despite the high expectations, the Augmented Reality technology is still not used massively.

Milgram and Kishino (1994) defined a continuum of real-to-virtual environments, in which Augmented Reality is one part of the general area of mixed reality, shown in Figure 1. In both augmented virtuality, in which real objects are added to virtual ones, and virtual environments (or virtual reality), the surrounding environment is virtual, while in Augmented Reality the surrounding environment is real.

Augmented Reality enhances a user's perception of and interaction with the real world. The virtual objects display information that the user cannot directly detect with his own senses. The information conveyed by the virtual objects helps a user perform real-world tasks (Azuma, 1997).

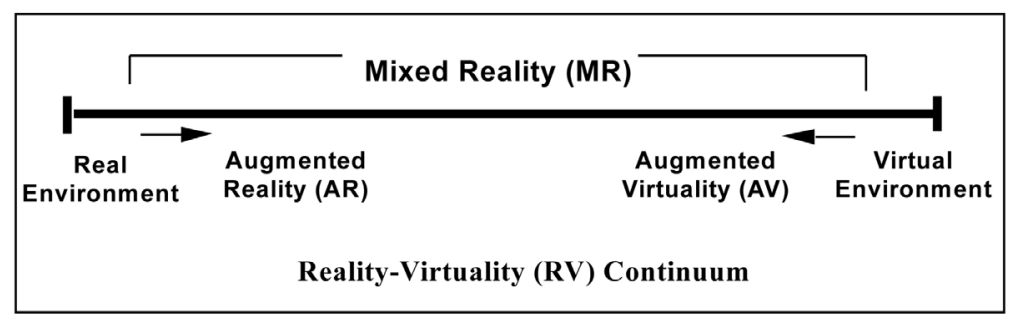

Source: Milgram and Kishino, 1994

Figure 1: Mixed Reality continuum. 
Lyu et al. (2005) state Augmented Reality as a variation of Virtual Reality as it is more commonly called. Virtual Reality technologies completely immerse a user inside a synthetic environment. While immersed, the user cannot see the real world around him. In contrast, Augmented Reality allows the user to see the real world, with virtual objects superimposed upon or composited with the real world. Therefore, AR supplements reality, rather than completely replacing it. Ideally, it would appear to the user that the virtual and real objects coexisted in the same space.

Bimber and Raskar (2005) extend this assertion in the contrast to traditional Virtual Reality. In Augmented Reality the real environment is not completely suppressed, instead it plays a dominant role. Rather than immersing a person into a completely synthetic world, Augmented Reality attempts to embed synthetic supplements into the real environment (or into a live video through the camera of the real environment).

For the assessment of Augmented Reality use appropriateness in terms of working aid for intellectually disabled persons for work in horticulture platform Wikitude was chosen. The second platform who was also been tested was Layar. Wikitude currently offers a comprehensive all-in-one SDK - Software Development Kit, including vision-based as well as location-based augmented reality platform for Android, iOS, Cordova, Xamarin, and others.

Both compared platforms allow views of the real world, supplemented by virtual information using a mobile device. Virtual information is supplemented with GPS position where should be displayed the requested supplementary information. On the specified GPS coordinates the user is able to see, through the mobile camera view and the necessary application software, not only the real world, but the real world complemented with the virtual information. Both platforms allow to create own applications and virtual layers using paid SDK. For testing by the research participants it was important to offer them final appearance of the user interface without the need for the development of extensive application.

Wikitude platform allows the user to create a simple virtual layer through integration with established user profile. Therefore it was selected for testing.

Currently, August 2015, it is also the world's most widely used platform for Augmented Reality and the world's leading augmented reality SDK (Wikitude $\mathrm{GmbH}, 2015$ ). The whole testing was performed under the Wikitude trial license.

\section{Results and discussion}

Through the creation of several virtual points, that have been placed by GPS coordinates into the area of the Department of Horticulture CULS - at Experimental and Demonstrational Station in Troja - Podhoří, there was tested the ability to view teaching materials using web based Wikitude application on the iPad2 and Android tablet Asus Transformer. Four virtual points were located in places where gardening activities has been taught and also in places intended for the verification of participants capabilities. When the participant stood on the specified location and looking through a camera of a tablet, on the display there was shown real view enriched by the virtual pictogram with reference to the educational material on the web. The required material is possible to trigger by clicking the pictogram on the virtual display, or subsequently in an internet browser.

Research was regularly attended by eight participants. Research participants were people with varying levels of mental disability. In all cases, these people permanently live in nursing homes or centers for persons with disabilities, they are not currently employed anywhere and within therapeutic activities they work in sheltered workshops, etc. The research was carried out on the same sample of people as in the case of article (Benda and Šmejkalová, 2015) Web Interface for Education of Mentally Disabled Persons for Work in Horticulture.

Interface has been selected on the basis of the conclusions of the same article (Benda and Šmejkalová, 2015):

- The education of mentally disabled persons is based on a continuous exchange of information highlighted by pictograms;

- Touch screen is the most suitable technology for controlling the web page or application.

It was also important to decide what kind of navigation items should be used. Based on prior research (Benda and Šmejkalová, 2015) it can be stated that the image navigation represented only by pictograms is groping whether the pictogram truly represents the desired horticultural operation. By combining this type of navigation with the text description all participants proved the best results. Correct orientation in the navigation consisting of the finding of learned pictogram 
and verifying the correctness also via text label. In this case all participants pressed intended navigation pictogram without hesitation. All participants correctly identified pictogram as a navigation item and pressed it. Performed observations and measured values show that the most appropriate form of an interface in the form of navigation is the use of pictograms with descriptive text label.

The following figure shows a draft of the application solution using the platform Wikitude. On selected GPS coordinates there has been placed a pictogram of gardening activity with a label. After clicking the pictogram it was possible to play a short video with instructions. The same pictograms are used throughout the whole educational process and knowledge evaluation.

Wikitude SDK (Wikitude GmbH, 2015b) code example appears as follows:

\section{//POI definition}

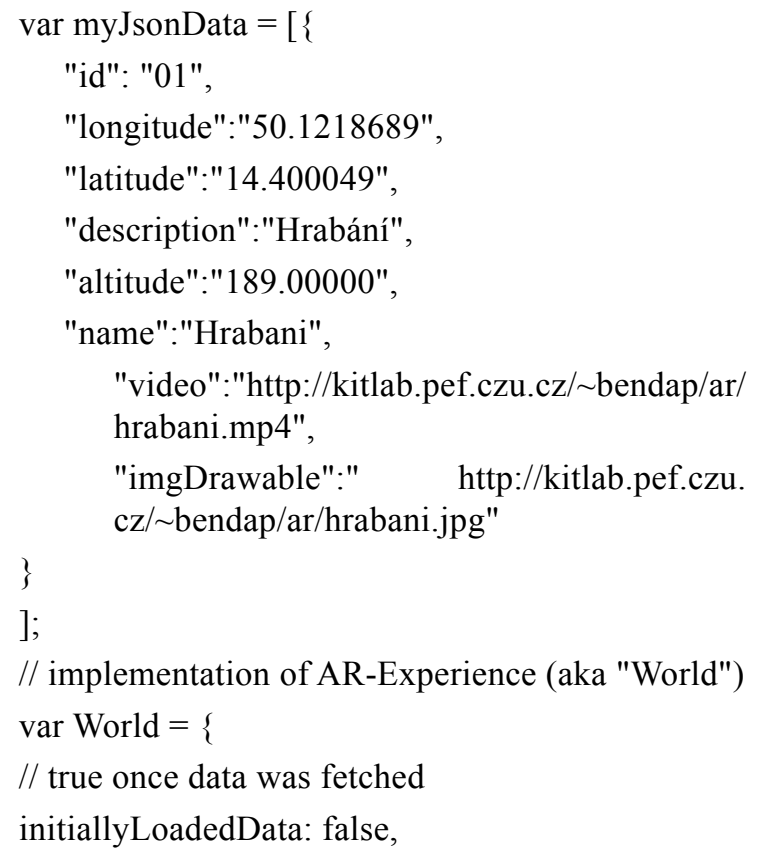

//called toinjectnewPOIdataloadPoisFromJsonData: function loadPoisFromJsonDataFn(poiData) \{

// empty list of visible markers

World.markerList $=[]$;

// start loading marker assets

World.markerDrawable_idle = new AR.ImageResource("assets/marker_idle. png");

World.markerDrawable selected $=$ new AR.ImageResource("assets/marker selected.png");

// loop through POI-information and create an AR.GeoObject (=Marker) per POI

for (var currentPlaceNr $=0$; currentPlaceNr $<$ poiData.length; currentPlaceNr++) \{ var singlePoi $=\{$

"id": poiData[currentPlaceNr].id,

"latitude": parseFloat(poiData[currentPlaceNr]. latitude),

"longitude": parseFloat(poiData[currentPlaceNr]. longitude),

"altitude": parseFloat(poiData[currentPlaceNr]. altitude),

"title": poiData[currentPlaceNr].

name,

"description": poiData[currentPlaceNr].description

"video":poiData[currentPlaceNr].video,

"url":poiData[currentPlaceNr].url

;

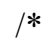

To be able to deselect a marker while the user taps on the empty screen, the World object holds an array that contains each marker.

$* /$

World.markerList.push(new Marker(singlePoi));

\}

World.

updateStatusMessage(currentPlaceNr + ' places loaded'); \},$\ldots$

The results of Augmented Reality utilization were not satisfactory. This form of material distribution 


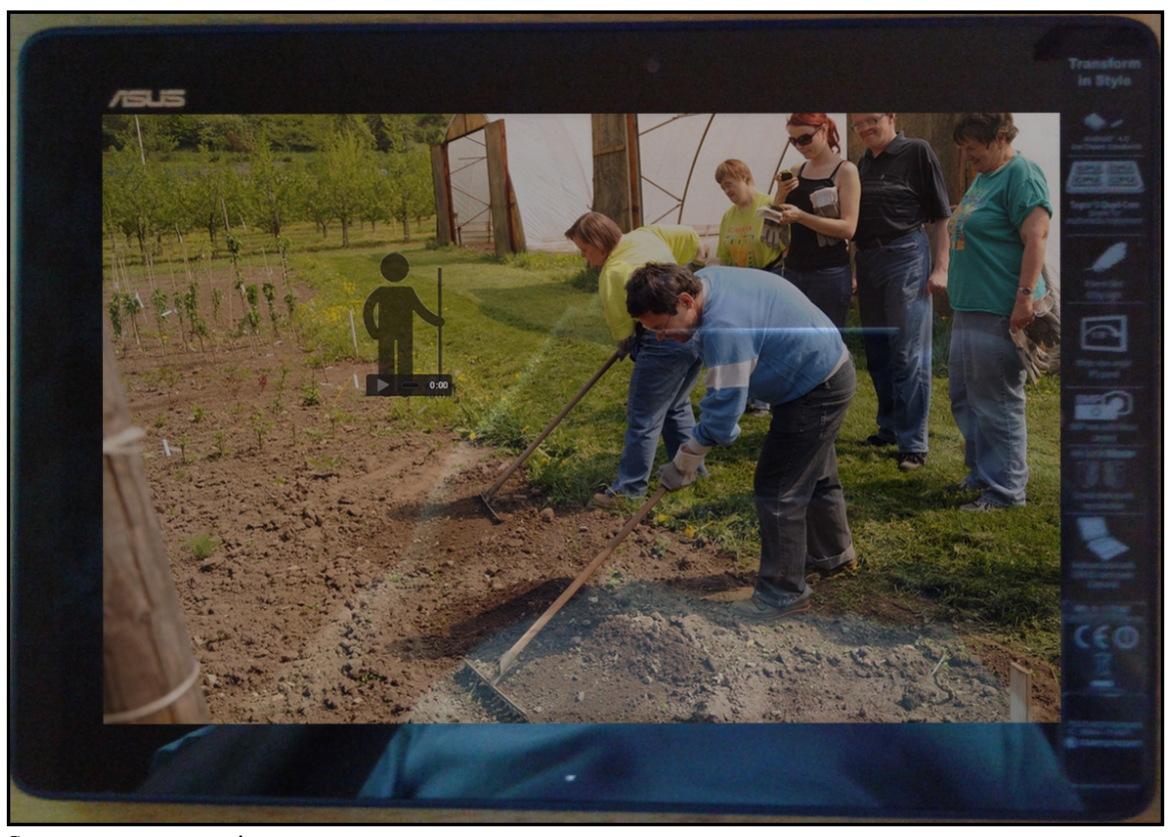

Source: own processing

Figure 2: Draft of the application solution.

was confusing for participants, and the need to orient themselves in space through the screen of the iPad2 or Android tablet was also very demanding. None of the research participants could view the material exposed in the form of a virtual point and use it effectively. The need to focus on the required operations outweighed own perception of distributed content. Interface and display method of Augmented Reality content should be considered not only in terms of accessibility, but also usability with more focus on each individual.

Usability test depends heavily on each individual user background, information literacy and previous experience with similar web applications. Without proper testing subject selection, it can provide vastly distorted results (Šimek, Vaněk and Pavlík, 2015).

Another issue is the possibility of automatic functionality to start the content based on GPS position only without requiring to trace the pictogram or a combination of both solutions.

\section{Conclusion}

Despite the great potential of Augmented Reality technology it is still not possible to recommend this type of education for people with intellectual disabilities for work in horticulture to support their work activities in real environment. On the basis of undertaken studies, this form of navigation in real environment is still too demanding and confusing for the most of research participants. But there is still scope for new research. E.g. creation of an application for mobile devices according to the principles of WCAG 2.0 accessibility methodology and to the principles of usability that would directly display needed material without requiring to control it manually. This kind of approach would allow the user easier orientation in space and easier handling the device. It is also possible to try other ICT for display Augmented Reality.

\section{Acknowledgements}

The knowledge and data presented in the present paper were obtained as a result of the Grant No. 20151007 of the CULS Prague Internal Grant Agency titled „Innovative approaches to the use of ICT in education for mitigation of social exclusion" and the Grant No. 20151039 of the FEM CULS Prague Internal Grant Agency titled „Utilization of open data in the agrarian sector". 
Corresponding author:

Ing. Petr Benda, Ph.D.

Department of Information Technologies, Faculty of Economics and Management

Czech University of Life Sciences Prague, Kamýcká 129, Prague 6 - Suchdol, 165 00, Czech Republic

E-mail: bendap@pef.czu.cz

\section{References}

[1] Azuma, R. T. A survey of augmented reality. Presence: teleoperators and virtual environments. 1997, Vol. 6, No. 4, p. 355-385. ISSN 1054-7460.

[2] Benda, P., Šmejkalová, M. Web Interface for Education of Intellectually Disabled Persons for Work in Horticulture. Agris on-line Papers in Economics and Informatics. 2015, Vol. 7, No. 1, p. 13 - 19. ISSN 1804-1930.

[3] Černá, M. Česká psychopedie. Speciální pedagogika osob s mentálním postižením (Czech psychopedy. Special pedagogics of mentally disabled persons). Prague: Karolinum, 2009, p. 222. ISBN 978-80-246-1565-3.

[4] Bimber, O., Raskal, R. Spatial augmented reality: merging real and virtual worlds. Wellesley: A K Peters, 2005, Vol. 13, p. 392. ISBN 15-688-1230-2.

[5] Denaes, C. Analogical Matrices in Young Children and Students with Intellectual Disability: Reasoning by Analogy or Reasoning by Association? Journal of applied research in intellectual disabilities: JARID. 2012, Vol. 25. ISSN 1360-2322.

[6] Goksu, I., Atici, B. Need For Mobile Learning: Technologies and Opportunities. 13 $3^{\text {th }}$ International Educational Technology Conference, Kuala Lumpur, Malaysia, 2013, p. 733-740. ISSN 2146-7366.

[7] Gomez, J. , Montoro, G, Torrado, J. C., Plaza, A. An Adapted Wayfinding System for Pedestrians with Cognitive Disabilities. Mobile Information Systems, Vol. 2015, Article ID 520572, p. 11. doi:10.1155/2015/520572.

[8] Hervas, R., Bravo, J. and Fontecha, J. An assistive navigation system based on augmented reality and context awareness for people with mild cognitive impairments. IEEE Journal of Biomedical and Health Informatics, 2014, Vol. 18, No. 1, p. 368-374. ISSN 2168-2194.

[9] Huguenin, N. Reducing overselective attention to compound visual cues with extended training in adolescents with severe mental retardation. Research in developmental disabilities. 2000, No. 21, p. 93-113. ISSN 0891-4222.

[10] Lyu, M. R. I., King, T. T., Wong, E., Chan, P. W. ARCADE: Augmented reality computing arena for digital entertainment. Proceedings / IEEE Aerospace Conference. 2005, p. 3264-3272. ISSN 1095-323x.

[11] Milgram, P., Kishino, F. A taxonomy of mixed reality visual displays. IEICE Transactions on Information Systems. 1994, Vol. E77-D, No. 12, p. 1321-1329. ISSN 0916-8532.

[12] Milgram, P., Colquhoun, H. A Taxonomy of Real and Virtual World Display Integration. Mixed Reality - Merging Real and Virtual Worlds, Omsha (Tokyo) - Springer Verlag, 1999, p. 5-30. ISBN 3-540-65623-5.

[13] Schmalstieg, D., Wagner, D. Experiences with Handheld Augmented Reality. Mixed and Augmented Reality, 2007. ISMAR 2007. $6^{\text {th }}$ IEEE and ACM International Symposium. 2007, p. 3-18. ISBN 978-1-4244-1750-6.

[14] Šimek, P., Vaněk, J., Pavlík, J. Usability of UX Methods in Agrarian Sector - Verification. Agris on-line Papers in Economics and Informatics. 2015, Vol. 7, No. 3, p. 49 - 56. ISSN 1804-1930.

[15] Tyrychtr et al. Current state of the art of ICT and information needs among Czech farms in the context of agribusiness. Agrarian perspectives proceedings of the $24^{\text {th }}$ International Scientific Conference, Prague, 2015. p. 487 - 494. ISSN 2464-4781. 
[16] Valenta, M., Müller, O. Psychopedie. Prague: Parta. 2003, p. 439. ISBN 80-7320-039-2.

[17] Van de Ven, J. A., de Haan. 2003. Mouse or touch screen. Computers in psychology. 2003, No. 7, p. 191-204. ISSN 0925-9244.

[18] Wikitude GmbH. Wikitude. 2015. [Online]. Available: http://www.wikitude.com/ [Accessed: 29 Aug 2015].

[19] Wikitude GmbH (2015b). Documentation Wikitude SDK web. 2015. [Online]. Available: http://www.wikitude.com/developer/documentation/htmlcss\#_48_INSTANCE_ iBoVq3ir5plH_=gettingstartedweb.html\%23getting-started [Accessed: 30 Aug 2015]. 